ENTREPRENEURSHIP AND SUSTAINABILITY ISSUES

ISSN 2345-0282 (online) http://jssidoi.org/jesi/

2019 Volume 6 Number 4 (June)

http://doi.org/10.9770/jesi.2019.6.3(14)

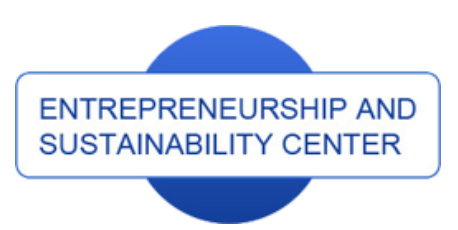

Publisher

http://jssidoi.org/esc/home

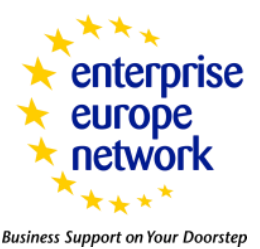

Business Support on Your Doorstep

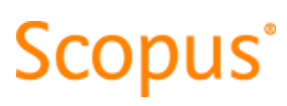

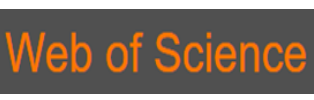

Clarivate
Analytics

\title{
TRANSFORMATIONAL COMMUNICATION VIA EVOLVING ETHICAL AND MORAL NORMS OF LITHUANIAN CIVIL SERVICE ORGANIZATIONS
}

\author{
Mindaugas Laužikas', Aistė Miliūtè² \\ ${ }^{1}$ Vilnius University Business School, Sauletekio Av. 22, LT-10225 Vilnius, Lithuania \\ ${ }^{1}$ Global Innovation Learning Ecosystem (GILE) Experts, Corradino Industrial Estate, Paola, Malta \\ ${ }^{2}$ Vilnius University Business School, Saulètekio Av. 22, LT-10225 Vilnius, Lithuania \\ JSC AKVAVITA, Neravu st. 100, Viečiūnai, Lithuania \\ E-mails: ${ }^{1}$ mindaugas.lauzikas@gmail.com ${ }^{2}$ aiste_miliute@yahoo.com
}

Received 19 February 2019; accepted 25 May 2019; published 30 June 2019

\begin{abstract}
A holistic approach to transformational communication (examined from the perspective of ethical and moral norms) requires investigation of its different aspects, such as communication efficiency (Paynton et al, 2016), evolution of ethics (Bud'urova, 2015), business ethics (Boatright, 2011; Norman, 2013, and etc.), transformational leadership (Uusi-Kakkuri, 2017; Jiang et al., 2017, and etc.), social capital (Growiec et al., 2017; Grieco, 2017, and etc.) or more specifically, ethical and moral norms (Orozco-Toro and Ferré-Pavía, 2013; García-Marzá, 2017). Such multi-facet interpretation of transformation communication explains various effects of communication which are experienced by any economy or organization undergoing reforms, transition from one development category to another or trying to enhance performance and reach sustainability while facing new global trends (related to networking, new technologies, innovation, knowledge sharing as well as bigger pressure from stakeholders to generate social value-added). Being more visible and closer to citizens, civil service organizations face the necessity to apply innovative communication means and collaboration-based approach to policy implementation, whilst many jeopardizing factors, such as insufficient social trust, the fear of failure, bureaucracy or lack of consistency, diversity and reward, call for implementation of various communication guidelines and ethical and moral norms-related documents. Thus, the research question "How to leverage the potential of transformational communication via ethical and moral norms in civil service organizations" is particularly relevant among economies which still face frequent manifestations of nepotism or fragile social trust dimensions. To avoid of triviality and to have a more profound analysis of the topic, the research is anchored in qualitative methodology, where results of semi-structured interviews with 20 Lithuanian civil servants support the designed conceptual model of transformational communication effects, which serves as a practical and useful education tool for policy makers and civil servants.
\end{abstract}

Keywords: transformational communication, evolving ethical and moral norms, leadership, civil service organizations.

Reference to this paper should be made as follows: Laužikas, M.; Miliūtė, A. 2019. Transformational Communication via Evolving Ethical and Moral Norms of Lithuanian Civil Service Organizations, Entrepreneurship and Sustainability 6(4): 1750-1761. http://doi.org/10.9770/jesi.2019.6.4(14)

JEL Classification: M130. 


\section{ENTREPRENEURSHIP AND SUSTAINABILITY ISSUES}

ISSN 2345-0282 (online) http://jssidoi.org/jesi/

2019 Volume 6 Number 4 (June)

http://doi.org/10.9770/jesi.2019.6.4(14)

\section{Introduction}

The Literature on Communication Efficiency is well established: communication experts Paynton et al (2016) overview the scientific publications throughout various periods, backing to the forties (Hovland, 1948; Morris, 1946; Nilsen, 1957; Schramm, 1946; Stevens, 1950). In spite of a long list of definitions of communication as well as classifications of its types and channels during the decades, the core fundamentals of communication remain the same. According to Paynton et al (2016), communication is the use of symbols to reveal the meaning/ essence. While shifting from linear/ mathematical to more transactional/ interactive type of communication, communication imbeds social value-added and positive externalities as well as affects social trust, attitude and perception of employees, stakeholders and society overall. Such evolution trends could be identified within positive practices of innovation-driven countries, such as Canada (TakingITGlobal, managed by Walraven, 2008) or the UK (Government Communication Service, the UK 2017), where commination (driven by innovation and social value-added via engagement of employees, society and community-building) is more long-term target; however, civil service organizations must be ready for the change, as modern technologies make their work more transparent, dynamic, because it is collaboration and knowledge-driven. Such transformation also calls for new social and cultural pillars, in particular, in the area of ethical and moral norms: being more interactive with stakeholders' civil service organizations face the necessity to embrace a set of new requirements, such as tolerating mistakes and learning from the past experience, social trust and evolving moral and ethical standards. As it is discussed by Bud'urova (2015), fact/value dichotomy is not so sharp in the context of evolutionary ethics which might justify morality on the basis of facts, while evolutionary theories (which might be not so value-free) should be interpreted with cautiousness and context-based.

From the business ethics point of you, Norman (2013) admits that evolution of ethics in business takes gradual steps and could be witnessed via continuous modification of classical paradigm of business ethics within scientific literature. While overviewing various scholars (such as Donaldson and Dunfee 1999; Heath 2006; Boatright 2011), Norman comes to conclusion that, apart from tackling the questions how individuals in business ought to behave, or what principles they might appeal, business ethics in the broadest sense address a rather vast spectrum of challenges and designs for firms, markets, regulations, and political oversight. According to Norman (2013) these specific challenges are interpreted in the context of micro-level virtue ethics, mid-level stakeholder theories, or macro-level theories of corporate social responsibility. Thus, business ethics is centred on continuous evolution of values, principles and standards which are in line with rapidly changing business and political environment as well as different trends across various industries and policies.

\section{Transformational Communication as Leadership}

Transformational communication is often interpreted in the context of transformational leadership. For instance, Uusi-Kakkuri (2017) in the dissertation "Transformational Leadership and Leading Creativity" argues that transformational leadership is an appropriate style for creative people, because intellectual stimulation and inspirational motivation help lead creative individuals and innovators. Transformational leadership is a popular and rapidly evolving scientific area worldwide: Jiang et al. (2017) interpret transformational leadership in the context of employees' motivation and their performance (it has positive influence on employees' sustainable performance in Chinese construction project); Aunjum et al. (2017) estimated that transformational leadership had positive and significant impact on employee motivation in the Banking sector of Pakistan, and it should be achieved via transformational and charismatic leadership. 


\section{ENTREPRENEURSHIP AND SUSTAINABILITY ISSUES}

ISSN 2345-0282 (online) http://jssidoi.org/jesi/

2019 Volume 6 Number 4 (June)

http://doi.org/10.9770/jesi.2019.6.4(14)

Within the report prepared jointly by the World Bank and the African Development Bank in cooperation with the African Union, Yonazi et al. (2012) emphasize the role of transformational communication in the context of society an stakeholders' transformation via modern technologies or technological competences of entrepreneurs and leaders. While focusing on Spanish local governments, Gálvez-Rodríguez et al. (2016) emphasize the role of Internet and community managers in engaging citizens, because community managers do not use social media efficiently to link local governments and citizens. Furthermore, positive experiences of more advanced innovation-driven economies, such as the UK, should be taken into consideration while engaging society and creating community spirit in various development areas. As for example, Science and Technology Committee, authorized by House of Commons of the UK (2017), encourage society engagement in science-related policies: public opinion should be fully captured in developing government policy where science is involved. Such practices can be applied in efficiency-driven countries or other areas of public administration; however, the context of cultural and social norms, social trust, knowledge diffusion, communication style, and many other social capital dimensions should be taken into account.

\section{Transformational Communication within Social Capital Dimensions}

Acknowledgment of the environment as part of social and cultural context was accentuated by many scholars. Fang et al. (2017) in their research tried to examine effects of normative beliefs, social norms and attitudes on behavioral intentions (research related to reusable tableware at theme park in Taiwan). The authors found out that c.a. one fifth of 391 respondents possessed pro-environmental behaviors, while the rest of interrogated respondents were significantly affected by social environmental education, which reveals the significance of education in transforming society via knowledge and inspiration.

Camargo and Passas (2017) within their paper presented during OECD Global Anti-Corruption \& Integrity Forum, address the specificity of cultural and social environment in the context of corruption: adoption of best anticorruption practices worldwide in some countries might be inefficient, for instance in Africa, Central Asia and the Caucasus, which could be associated with discrepancy between formal rules and informal practices. While interpreting the power of transformational ethics on citizens, the authors explain the social acceptability of corrupt acts by citizens' orientation to tactical, more practical, informal and short-term benefits, as well as a rather fragmented value created by public administration organizations. From this perspective, integration of informal practices and society engagement techniques into anti-corruption strategies or official policies could contribute to more sustainable and effective decisions, and, in parallel, stronger social image of civil service organizations.

Within the social capital structure, examined by Growiec et al. (2017), network degree (number of social ties), network centrality (bridges among otherwise disconnected sub-networks), bridging (social ties among dissimilar others), and bonding social capital (social ties among similar others) are anchored in the context of social trust and willingness to co-operate. According to authors, these network dimensions are strongly and positively linked to individual incomes; while social individuals' life satisfaction is determined primarily by the number of social ties an individual hold (network degree). Given the growing importance of collaboration, communication efficiency (which in the conceptual model, developed by the par author, refers to society engagement, community gathering, and creative leadership and specialists) is critical, because it leads to reshaped dimensions of social capital and realigned attitudes to current globalization context (see Figure 1). From the perspective of stronger ties among stakeholders, evolving ethical and moral norms call for modern technologies and practical communication tools enabling knowledge sharing and creativity enhancement. The conceptual model introduces a set of effects, which a modern organization is eager to reach, if effective transformational communication-related decisions are taken. 
ENTREPRENEURSHIP AND SUSTAINABILITY ISSUES

ISSN 2345-0282 (online) http://jssidoi.org/jesi/

2019 Volume 6 Number 4 (June)

http://doi.org/10.9770/jesi.2019.6.4(14)

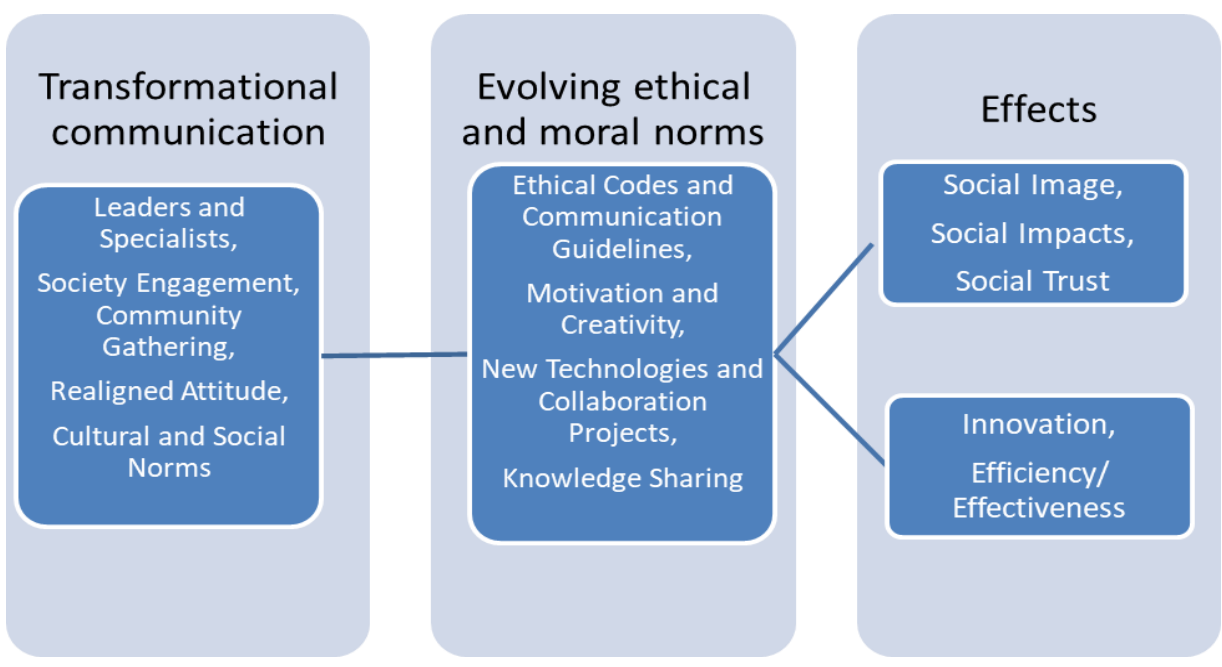

Fig. 1. The Conceptual Model of Transformational Communication Effects

Source: prepared by paper author

Grieco (2017) reveals similar arguments regarding impacts of social capital while emphasizing the element of partnerships, which is directly related to communication and serves as a tool for strategy development: it should broaden relationships between employees and partners; moreover, all social capital dimensions (cognitive, relational, structural/ network-based) positively influence the innovation capability. On the other hand, citizens and other stakeholders, driven my modern technologies, require more transparency, engagement, knowledge sharing and shared-value creation (which are directly related to different social capital dimensions, such as social trust, fear of failure or opportunity recognition).

\section{The Role of Ethical and Social Norms in Transformational Communication}

To better understand the context of communication (oriented to transformation and value/ attitude alignment as well as society engagement) it is important to identify the main effects and reinforcement principles of ethical and social norms. García-Marzá (2017) introduces the model of 'Ethical Auditing', which links three elements: perception, verification and adequacy. According to the author, insufficient compliance between commitments and regulated conduct, both at planning and execution stages, emerge as a barrier to creating social value-added (thus, affects communication of the information regarding social responsibility in organizations, which, in parallel, influences attitude, perception and social image).

García-Marzá (2017) adds that ethics of communication might be used as the basis to develop mechanisms of transparency and participation, which is essence of transformational communication. The author underlines 4 elements, which are necessary to reinforce the ethics of communication: ethical code of conduct, social responsibility reports, ethics committee, and ethics hotline (alerts and complains system). Given the lack of transparency in public administration organizations, due to insufficient sustainability and poor society engagement, ethical audit should be external to organizations and help seek consensus among various stakeholders (Sorsa, 2008; Orozco-Toro and Ferré-Pavía, 2013).

In light of technological innovation and emerging artificial intelligence, communication cannot be interpreted only in the context of human capital. Apart from formalized and communicated values in professional codes of ethics (which often implies machine-type ethical reasoning, knowledge development, and decision-making): Otterlo (2017) emphasizes that legal ways of formalizing behavior and communication might be too slow, 


\section{ENTREPRENEURSHIP AND SUSTAINABILITY ISSUES}

ISSN 2345-0282 (online) http://jssidoi.org/jesi/

2019 Volume 6 Number 4 (June)

http://doi.org/10.9770/jesi.2019.6.4(14)

compared to technological innovation; therefore, ethical codes as guidelines are more popular. Many authors, who were analyzed by Otterlo (2017), believed that it was possible to efficiently link technology with ethical codes if artificial intelligence was more responsible or accountable (Diakopoulos 2016; Etzioni and Etzioni, 2016), and private information was protected (Tene and Polonetsky, 2014; Tvaronavičienė 2018; Davidavičienė et al., 2019).

Furthermore, many civil service organizations try to encourage creativity and improve transparency; the lack of transparency, particularly in decision-making, is a key challenge among public administration organizations. Continuous learning and new knowledge application in technology might help obey human values and norms (Abel et al 2016) and reshape values and principles (Taylor et al. 2017). Although it is difficult to cover a rich variety of complex knowledge domains by technology, due to tacitness of knowledge, Otterlo (2017) suggests formalizing present fundamentals of ethical codes via suitable computational logics, which could make ethical and moral norms-related communication more value-adding, engaging, and efficient.

Given a complex transformation experience from centrally planned Soviet Innovation Systems to holistic knowledge-driven innovation system, many CEEC countries, such as Lithuania, possess insufficient social trust; thus, transformational leadership and communication are offset by the fear of failure, uncertainty avoidance, and lack of trust (Laužikas and Dailydaitè, 2015). Moreover, various stakeholders (civil service organizations, private companies, customers/ clients, information centers or education institutions, R\&D transfer organizations, and citizens) need communication facilitators or community spirit building tools. Weak risk management and strategic planning competencies along with uncertainty avoidance diminish the innovation progress in those economies; thus, society engagement via new technologies and the time of changes is critical.

\section{Methodology}

Ethical and moral norms, organizational philosophy, values and principles are fundamentals to communication efficiency during the time of change: these factors are inter-connected and manifest as the main drivers of transformational communication, which might lead to society engagement, community building and stronger social image (Curristine et al, 2007). These effects are particularly important to civil service organizations, as they are centred on social value-added and liaisons between political priorities and strategies. Moreover, ethical codes and behavior guidelines refer to the social capital dimensions, and, to be more precise, to communication plans during the time of change, future communication strategies as well as communication descriptions of various job positions (it affects employee motivation, creativity, combination of employees' and organizational expectations as well as performance efficiency and sustainability within a network of diverse stakeholders) (Government Communication Service, the UK 2017).

Having scientific literature analysis results summarized in the conceptual model of Transformational Communication Effects, the semi-structured qualitative expert interviews with 20 civil service specialists from Lithuanian civil service is chosen to better understand the transformational communication challenges and opportunities ethical and moral norms could bring to public administration organizations in Lithuania, along with the reasons and tactics of choosing a particular communication type or strategy.

Based on the developed conceptual model, the semi-structured questionnaire contained a few blocks of questions, related to: communication during the time of change, communication enhancement techniques, the role of Human Resource Management within communication processes, innovation and creativity as well as the potential effects of ethical and moral norms. The valid responses from 20 experts were received on the 5th December 2017, and all the respondents accorded to 3 main criteria in terms of: experience, education and their relation to the Communication area. 


\section{ENTREPRENEURSHIP AND SUSTAINABILITY ISSUES}

ISSN 2345-0282 (online) http://jssidoi.org/jesi/

2019 Volume 6 Number 4 (June)

http://doi.org/10.9770/jesi.2019.6.4(14)

After ingenious analysis of research results, the conceptual model was backed by experts' insights and the transformational communication model was adjusted in order to provide pertinent recommendations for civil service organization in Central and Eastern European Countries. Civil service organizations are recommended to use the revised model while valuating effects of transformational communication before and after the ethical codes and communication guidelines were introduced (both in the shorter and longer run), while applying a set of concrete measures in line with their organizational context. The present publication could serve as a reference to further research, focused more on indicators representing effects of transformational communication.

\section{Research Results: Sustainability through Evolving Ethics and Communication}

In light of emerging significance of social value-added and bigger attention to positive externalities across various types and status organizations, experts of Lithuanian civil service organizations also address these new trends while emphasizing social impacts and ethical/ moral communication within networks. An efficient ethical code might serve as non-financial motivation means while encouraging various social innovation and value-adding activities; in parallel, it affects employee turnover and main career drivers: four experts agreed that ethical and moral norms might be among the most important reasons for career choice or resigning from public administration organizations. One expert, representing younger and less experienced civil servants, emphasized that non-financial remuneration was not adequate to efforts of getting a civil service job and demonstrating efficient performance to stakeholders. Apart from small wages, the expert did not find wok activities as corresponding to his/ her job position and qualifications along with unequal assessment of employees' performance due to subjective reasons and nepotism, in addition to conservatism and lack of innovation (all these areas could be improved thanks to ethical codes, which could affect employee turnover and satisfaction).

The most of the experts admitted that management style and personality might endanger social trust, respect and satisfaction among employees; it is particularly acknowledged during the time of management change. As for example, one Head of ministry department invited to his/ her team to demonstrate how positive attitude and smooth communication between managers and employees might affect the psychological climate and innovation culture of the department via an ethical code. Another more experienced expert emphasized the role of selfesteem and pride which should be encouraged via ethical codes, as civil servants might feel the lack of support and confidence from society along with insufficient financial reward.

As it could be expected, younger experts with modest experience in civil service underlined another important function of ethical codes, which is a guideline in building and managing teams: competences, attitude and commitment should be more important than nepotism; initiatives and creative leaders should be supported; listening and empathy-based communication should be established, while political priorities should not hide misbehavior and breach of ethical and moral norms. However, there were experts who could not acknowledge team-building and team-management manifestations at all, which eliminated the possibility to discuss regarding the role of creative, talented and innovative teams. Five experts suggested that ethical codes were necessary in civil service, but they should be implemented in a more employee-friendly and natural way. One expert suggested 10 recommendations' format while avoiding strict rules and legal aspects, while another specialist emphasized self-discipline and authority-based, yet explicit code; only one respondent underlined communication of ethical principles and norms (along with implementation) among employees: there should be no excuse to unethical behavior, and employees should encourage each other to be moral and ethical.

The fragmented and rather conservative approach to ethical codes was illustrated by the fact that no one among experts emphasized flexibility and sustainability-related aspects, such as the role of ethical codes during the time of change, communication of strategic targets, internal communication, opportunities of strengthening social image and encouraging creativity, as well as innovation and modern technologies. Such result shows that civil 


\section{ENTREPRENEURSHIP AND SUSTAINABILITY ISSUES}

ISSN 2345-0282 (online) http://jssidoi.org/jesi/

2019 Volume 6 Number 4 (June)

http://doi.org/10.9770/jesi.2019.6.4(14)

servants do not have sufficient experience and knowledge regarding impacts and implementation possibilities of ethical codes.

Having rather limited knowledge on ethical and social norms and incapability to identify innovative ways to engage society and build community, civil service organizations should strengthen their strategic collaboration in all the weaker areas. Joining associations, digital networks, startup ecosystems, entrepreneurship research centers, clusters and associations of various industries, as well as entering into co-operation agreements with new Lithuanian and international partners could elevate communication efficiency to a higher level via common events, projects, research, and knowledge sharing. This will affect cost structure, image, internationalization level, synergy effects, society, stakeholders' satisfaction, and social trust. Nowadays, it is not necessary to attend various projects physically: many activities are carried out online or via mobile technologies (in particular the dissemination part of projects and activities).

Notwithstanding the importance of strategic partnerships in communication during the time of change, only one expert emphasized the role of external consultants while communicating among different-level civil servants during the time of change. As it was expected this expert represented the younger group of civil service experts. Given modest team-management competences, two experts mentioned the role of external experts in trainings and consultancy in this area while inviting university professors, experts from partner-institutions or the best specialists of different areas. The lacking contribution from external experts in team-building was more often mentioned than the value-added of internal creative leaders, which shows that social trust and knowledge sharing inside an organization is smoother than externally. Experts did not mention the importance of engaging external partners into various teams due to heavy bureaucracy as well as vacant experience of communicating in a culturally and socially diverse environment. Communication among various partners should be accelerated via the use of modern technologies, such as hubs, applications, artificial intelligence, and etc. Strong partners could also contribute to cheaper and more efficient lifelong learning, positive image of civil service organizations, community spirit, society engagement, and sustainability.

Undeveloped civil servants' competences in various business administration areas diminishes the role of strategic partnerships in strategy development, limits the opportunities of reshaping political priorities as well as endangeres communication of strategic plans and expectations to society. On the other hand, strategic partners could help in communication of strategies and strategy implementation progress to other stakeholders. The quality of performance is a key factor of organizational social image, and it is unlikely to improve it without key strategic partners.

New process innovation calls for innovative management of change, and communication efficiency is a catalyst during the time of change; however, only one expert with Business education background and nearly 20 years of experience in civil service emphasized the role of leaders in liaising different-level employees, negotiating, presenting suggestions and communicating the information. A team of leaders from different departments, built uniquely for communication during the time of change, is recommended, and horizontal communication should be based on modern technologies. Engaging employees in planning and managing changes is critical; however, only 4 civil servants emphasized the role of innovation and knowledge management while communicating with employees during the time of change. The ones having relatively less experience in civil service organizations accentuated the function of ideas generation and collection via technologies, art, life meetings and interactive seminars with innovation professors. Within each department and among departments, it is suggested to build smaller groups in order to discuss various challenges and solutions related to the change. The more experienced respondents were more conservative and mentioned traditional communication options, such as formal meetings with employees while presenting the change, new tasks and requirements, which are more in line with "TopDown" management approach. 


\section{ENTREPRENEURSHIP AND SUSTAINABILITY ISSUES}

ISSN 2345-0282 (online) http://jssidoi.org/jesi/

2019 Volume 6 Number 4 (June)

http://doi.org/10.9770/jesi.2019.6.4(14)

Innovation requires innovative marketing and communication tools; thus, it is impossible to run social image strengthening campaigns without application of Social Medias, and vice versa, external communication should be driven by new ways of engaging and gathering society. However, only one expert admitted that civil service organizations must use innovation via dissemination of good practices and activities as well as through interaction with society (while using online forums and meetings, social events, hubs, software applications, and etc.).

Within organization with limited financial motivation possibilities, innovation, and in particular innovation climate, might be a great solution. In light of rather conservative bureaucratic structures in Lithuanian civil service organizations, six experts emphasized the role of innovation from the context of non-financial rewards. The younger and less experienced civil servants were focused on innovation climate and leisure activities (community spirit; singing, dancing and sport activities; days with animals, lunch and dinner together, book club, consulting each other in various areas, voluntary work in organizations which take care of animals and elder people, leisure room, office kitchen, various informal social events, and etc.) as well as more flexible schedules or showing respect towards their work (for instance, nominations and reward of best employees, dissemination of good work practices on Intranet). The older and more experienced experts emphasized more practical aspects, such as flexible schedules, work from home, workplace comfort, interaction with colleagues, healthcare, medicine insurance, discounts in sport clubs, various premiums for innovative performance, seminars of employees' choice, and etc. Such trend reveals the untapped team-building potential, where, based on project and activity specificity, organizations could develop mixed teams (in terms of age, gender and nationality) in order to emphasize innovation, creativity and talent management at teams' level. It is particularly important in the context of limited cultural diversity while addressing many ethical and moral norms- related challenges.

It is not likely for civil service organizations to attract innovative and edge people if bureaucratic procedures are too long (still many paper documents in use, a lot of proofreading and confirmation signatures involved; too long processes and limited autonomy in decision-making), new technologies are not applied (2 experts noted the necessity to revive Intranet), and social image of public administration organizations is still negative.

The lack of innovativeness in Lithuanian Civil Service Organizations might be proved by the willingness to create "Innovative Ideas Bank", which was expressed by 10 experts. Although they do not specify a form or technology for ideas collection, they admit that it would be a great non-financial motivation mean; however, one of the most experienced and human resource management-related experts (who has been working in civil service organizations for nearly 25 years) emphasized the importance of preparing employees for this innovation, as it might be led by opposition and skepticism. This finding indicates the lack of communication between heads of departments and employees, as leaders do not feel and acknowledge employees' perception and expectations.

While adjusting the conceptual model of transformational communication effects, based on research results, the experts' responses were more concrete and centered on internal challenges rather than on multi-facet holistic approach to communication: experts emphasized the importance of applying more "Bottom-up" model (due to the lack of horizontal communication and severe rules), while limited financial reward opportunities and insufficient competences called for informal learning and non-financial reward means (for instance, team building or various events). Respondents pointed out at the transformational nature of civil service organizations (which is related to constant changes in political priorities and ongoing reforms); therefore, they lacked concrete communication plans during the time of change, based on positive experiences of other countries as well as profound expertise of external experts, such as university professors or even corporate partners, As it could be expected, the specialists' underlined communication effects were in line with scholars' interpretation. 
ENTREPRENEURSHIP AND SUSTAINABILITY ISSUES

ISSN 2345-0282 (online) http://jssidoi.org/jesi/

2019 Volume 6 Number 4 (June)

http://doi.org/10.9770/jesi.2019.6.4(14)

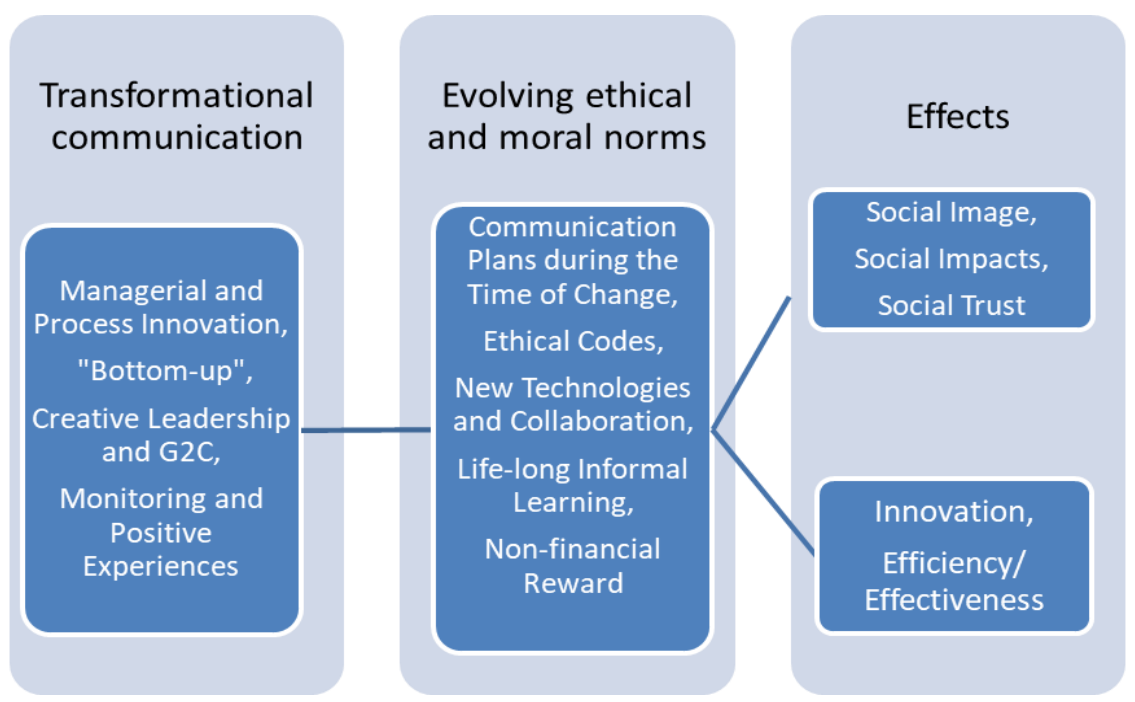

Fig. 2. The Revised Conceptual Model of Transformational Communication Effects

Source: prepared by paper author, based on research results

In the context of knowledge diffusion among different- level employees, it is important to identify the main reasons why specialists choose or leave civil service organizations: for some of them it is the opportunity to use knowledge and skills acquired at university in order to enhance their competences; for others it is related to working hours; while innovation-driven candidates or employees want to be value-adding to entrepreneurship conditions, innovation processes, sustainability of the countr. However, only 3 experts accentuated the role of innovation on career choice. It is also in line with another important dimension of innovation commercialization, which is team-building; only three experts mentioned this factor in the context of teams' innovation. This area is unknown and distant to experts: they have a rather negative perception on team-building in their organizations due to lacking competences, fragmented information and insufficient co-operation among colleagues both formally and informally. The informal communication was missed by 4 experts (dominant answer among younger and less experienced experts): they acknowledged the role of inter-personal communication in order to know and understand each other better, to share knowledge, experience and ideas, to build social trust and to understand better strategic targets of the organization.

It is interesting to note that experts distinguish the difference between creative leaders and specialists and suggest involvement of both groups in teams, ideas generation and strategic planning, along with employees' and society engagement. One of the youngest experts with two-year experience in Civil Service suggest the initiative "Help Your Colleague", which encourage social trust among colleagues via the system of stickers rewarded for assistance and support by other colleagues (employees with the largest number of stickers get remuneration). Moreover, only one expert interprets innovation in the context of cultural and social norms (moral and emotional state of a person or ethics), which shows the lack of holistic approach to innovation and creativity as well as untapped potential of techniques which refer to ethical and moral norms.

\section{Conclusions}

Ethical and moral norms have a vast spectrum of effects on sustainable performance of Lithuanian civil service organizations (such as, efficiency, social image, society engagement, and social impacts); however, transformational communication (including a list of aspects, such as networking, realignment of perception and attitude, building and engaging community, running various-type innovation, enhancing creativity and leadership, 


\section{ENTREPRENEURSHIP AND SUSTAINABILITY ISSUES}

ISSN 2345-0282 (online) http://jssidoi.org/jesi/

2019 Volume 6 Number 4 (June)

http://doi.org/10.9770/jesi.2019.6.4(14)

strengthening social trust, motivation, and etc.) is unlikely possible if an organization does not have its philosophy and techniques helping to apply ethical and moral norms in projects and activities.

It is recommended to engage employees and society in the development process of organizational ethical codes: starting from individual ethical codes, professional philosophy of each employee, and only then moving to the stage of behavior guidelines, communication documents and organizational ethical codes (Ferguson et al, 2016). This process requires ingenious research and profound comparison analysis of various examples of ethical codes worldwide, horizontal communication tools, and engagement of society via modern technologies, along with the presence of the highest-level governors and foreign specialists, and empowerment of leaders. Having clear code development stages and targets, ethical codes can be interpreted in the context of marketing, as they can strengthen social image of organizations via community building (for instance, social events), liaising organizational philosophy with cultural and social norms of community, including values and behavior principles.

A cross-departmental committee, specifically built for ethical code development purpose, should engage citizens and other stakeholders in decision-making and ethical code development process via new technologies and interactive events. Moreover, transformational leaders should acknowledge and address different dimensions and challenges related to social capital (for instance, social trust, the fear of failure, lack of self-esteem or nepotism), while relying on a more holistic and complex approach to transformational communications. The ethical and moral norms should be realigned accordingly in order to correspond to current trends across various economies, industries, and policies.

\section{References}

Abel, D.; MacGlashan, J.; Littman, M. 2016. Reinforcement of learning as a framework for ethical decision making, The Workshops of the Thirtieth AAAI Conference on Artificial Intelligence, Ethics, and Society: Technical Report WS-16-02:8. https://pdfs.semanticscholar.org/4f3b/3459cd39ef417966b9859dfd69659327d99a.pdf

Aunjum, A.H.; Abbas, G.; Sajid, M. 2017. Transformational leadership and employee motivation in banking sector of Pakistan, Advances in Economics and Business, 5(9): 487 - 494. https://doi.org/10.13189/aeb.2017.050901

Boatright, J.R. 2006. What's Wrong - and What's Right - with Stakeholder Management, Journal of Private Enterprise, 21 (2): 106-130, ISSN 0890-913X.

Bud'urova, B. 2015. Evolution of Ethics, E-LOGOS - Electronic Journal for Philosophy, 22(1): 71-76. ISSN 1211-0442 https://doi.org/10.18267/j.e-logos.415

Camargo, C.B.; Passas, N. 2017. Hidden agendas, social norms and why we need to re-think anti-corruption, OECD Global AntiCorruption \& Integrity Forum, p. 17. https://www.oecd.org/cleangovbiz/Integrity-Forum-2017-Baez\%20Camargo-Passas-hidden-agendassocial-norms.pdf

Curristine, T.; Lonti, Z.; Joumard, I. 2007. Improving public sector efficiency: challenges and opportunities, OECD Journal on Budgeting, 7(1). ISSN 1608-7143.

Davidavičienė, V.; Raudeliūnienè, J.; Tvaronavičienė, M.; Kaušinis, J. 2019. The importance of security aspects in consumer preferences in electronic environment, Journal of Security and Sustainability Issues, 8(3): 399-411. http://doi.org/10.9770/jssi.2019.8.3(9)

Diakopoulos, N. 2016. Accountability in algorithmic decision making, Communications of the ACM, 59(2): 56-62.

Donaldson, T.; Dunfee, T.W. 1999. Ties That Bind: A Social Contracts Approach to Business Ethics. Cambridge, MA: Harvard Business School Press, p. 320, ISBN 10: 0875847277.

Etzioni, A.; and Etzioni, O. 2016. Designing AI systems that obey our laws and values, Communications of the ACM, 59(9): 29-31. 


\section{ENTREPRENEURSHIP AND SUSTAINABILITY ISSUES}

ISSN 2345-0282 (online) http://jssidoi.org/jesi/

2019 Volume 6 Number 4 (June)

http://doi.org/10.9770/jesi.2019.6.4(14)

Fang, W.T.; Ng, E.; Wang, Ch. M.; Hsu, M.L. 2017. Normative beliefs, attitudes, and social norms: people reduce waste as an index of social relationships when spending leisure time, Sustainability, 9(1696): 18. www.mdpi.com/journal/sustainability

Ferguson, J.; Ronayne, P.; Rybacki, M. 2016. Comparing Leadership Challenges: Civil Service vs. Private Sector. White Paper: Part 2 in a 3-Part Series, Centre for Creative Leadership, p. 20.

https://www.ccl.org/wp-content/uploads/2016/02/ComparingLeadershipChallenges.pdf.

Gálvez-Rodríguez, M.M.; Haro-de-Rosario, A.; Caba-Pérez, C. 2017. Improving citizens' online engagement via community managers: an explanatory study, Regional Government of Andalusia (Spain), Department of Innovation, Science and Enterprise: [Research Projects P10SEJ-06628 and P11-SEJ-7700], pp. 1-17. https://doi.org/10.1080/1369118X.2017.1315442

García-Marzá, D. 2017. From Ethical Codes to Ethical Auditing: an Ethical Infrastructure for Social Responsibility Communication, El profesional de la información, 26(2): p. 9. http://www.elprofesionaldelainformacion.com/contenidos/2017/mar/13 esp.pd

Government Communication Service, 2017. The UK Government Communication Plan: Our Priorities in 2017/2018, Crown Copyright, p. 44. https://gcs.civilservice.gov.uk/wp-content/uploads/2017/08/6.3149_CO_GCS-Comms-Plan_FINAL_WEB.pdf.

Grieco, A.A.M. 2017. Does social capital dimensions foster innovation capabilities?, Doctor Thesis, directed by Susana Carla Farias Pereira at Escola de Administração de Empresas de São Paulo, p. 104. https://bibliotecadigital.fgv.br/dspace/bitstream/handle/10438/18529/Final2-Tese-Guto-Nova-22-7-2017.pdf.

Growiec, K.; Growiec, J.; Kamiński, B. 2017. Mapping the Dimensions of Social Capital, SGH KAE Working Papers Series, No. 2017/025, p. 75. http://kolegia.sgh.waw.pl/pl/KAE/Documents/WorkingPapersKAE/WPKAE_2016_025.pdf

Heath, J. 2006. Business Ethics without Stakeholders, Business Ethics Quarterly, 16(4): 533-57.

House of Commons Science and Technology Committee 2017. Science communication and engagement, Eleventh Report of Session 201617 Report, together with formal minutes relating, p. 35. https://publications.parliament.uk/pa/cm201617/cmselect/cmsctech/162/162.pdf.

Hovland, C.I. 1948. Social communication, Proceedings of the American Philosophical Society, 92(5): 371-375.

Jiang, W.; Zhao, X.; Ni, J. 2017. The Impact of Transformational Leadership on Employee Sustainable Performance: The Mediating Role of Organizational Citizenship Behavior, Sustainability, 9(9): p. 17. https://doi.org/10.3390/su9091567

Laužikas M.; Dailydaite, S. 2015. Impacts of social capital on transformation from efficiency to innovation-driven business, Journal of Business Economics and Management, 16(1): 37-51. https://doi.org/10.3846/16111699.2012.754374

Morris, Ch. 1946. Signs, language, and behavior. New York: Braziller, p. 376.

Nilsen, T.R. 1957. On defining communication, Speech Teacher, 6(1):10-17.

Norman, W. 2013. Business Ethics. The International Encyclopedia of Ethics. Edited by Hugh LaFollette, Blackwell Publishing Ltd, pp. 652-668. https://doi.org/10.1002/ 9781444367072.wbiee719

Orozco-Toro, J.A.; Ferré-Pavía, C. 2013. La comunicación estratégica de la responsabilidad social corporativa, Razón y palabra, No. 83, p. 20. http://www.razonypalabra.org.mx/N/N83/V83/20_OrozcoFerre_V83.pdf

Otterlo, M. 2017. From Algorithmic Black Boxes to Adaptive White Boxes: Declarative Decision-Theoretic Ethical Programs as Codes of Ethics. Vrije Universiteit Amsterdam, The Netherlands, arXiv:1711.06035v1, p.7. https://arxiv.org/pdf/1711.06035.pdf

Paynton, S. T.; Hahn, L. K.; Lippert, L. (2016). Survey of Communication Study. Wikibooks, the Free Textbook Project: https://en.wikibooks.org/wiki/Survey_of_Communication_Study.

Schramm, W. (Ed.) 1948. Communication in modern society: fifteen studies of the mass media prepared for the University of Illinois Institution of Communication Research. Urbana, IL: The University of Illinois Press, p. 252.

Sorsa, V.P. 2008. How to explain socially responsible corporate actions institutionally: theoretical and methodological critique, Electronic journal of business ethics and organization studies, 13(1): 10. https://jyx.jyu.fi/dspace/handle/123456789/25416.

Stevens, S.S. 1950. Introduction: A definition of communication, The Journal of the Acoustical Society of America, 22(6): 689-690. 


\section{ENTREPRENEURSHIP AND SUSTAINABILITY ISSUES}

ISSN 2345-0282 (online) http://jssidoi.org/jesi/

2019 Volume 6 Number 4 (June)

http://doi.org/10.9770/jesi.2019.6.4(14)

Taylor, J.; Yudkowsky, E.; LaVictoire, P.; Critch, A. 2017. Alignment for advanced machine learning systems. MIRI.

https://intelligence.org/2016/07/27/alignment-machine-learning/

Tene, O.; Polonetsky, J. 2014. A theory of creepy: technology, privacy, and shifting social norms, Yale Journal of Law and Technology, 16(1): 45. http://digitalcommons.law.yale.edu/cgi/viewcontent.cgi?article=1098\&context=yjolt

Tvaronavičienė M. 2018. Towards internationally tuned approach towards critical infrastructure protection, Journal of Security and Sustainability Issues, 8(2): 143-150. https://doi.org/10.9770/jssi.2018.8.2(2)

Uusi-Kakkuri, P. 2017. Transformational leadership and leading creativity, Academic Dissertation at University of Vaasa, Faculty of Business Studies, Department of Management, Vaasan yliopisto, p. 283: ISBN 978-952-476-748-4, ISSN 0355-2667. http://www.uva.fi/materiaali/pdf/isbn 978-952-476-749-1.pdf

Walraven, K. 2008. TIGed Update 2.4., TakingITGlobal, Nov. post.

https://www.tigweb.org/community/newsletters/html/view.html?edition=t283\&layout=tiged

Yonazi, E.; Kelly, T.; Halewood, N.; Blackman, C. 2012. The Transformational use of information and communication technologies in Africa, The World Bank and the African Development Bank, p. 166. http://siteresources.worldbank.org/EXTINFORMATIONANDCOMMUNICATIONANDTECHNOLOGIES/Resources/282822$\underline{1346223280837 / M a i n R e p o r t . p d f}$

\section{Biographical notes}

Dr. Mindaugas LAUŽIKAS is a Professor at Vilnius University Business School, Doctor of Economic Sciences, Director of GILE Experts (Malta). Lecturing experience in countries, such as Georgia, Sweden, France, Spain, Italy, Malta, Moldova, South Korea and Lithuania, is supported by publications in the field of knowledge economy, entrepreneurship and innovation. Research interests: national systems of innovation, entrepreneurship, knowledge and innovation management, innovation and human resource strategies.

ORCID ID: http://orcid.org/0000-0002-6113-7794

Aistė MILIŪTÉ is a teacher/researcher at Vilniaus universiteto Verslo mokykla and entrepreneur within the mineral water and healthcare industries, a founder of AKVAVITA company.

ORCID ID: http://orcid.org/0000-0002-9667-3730

Register for an ORCID ID:

https://orcid.org/register

Copyright (C) 2019 by author(s) and VsI Entrepreneurship and Sustainability Center

This work is licensed under the Creative Commons Attribution International License (CC BY).

http://creativecommons.org/licenses/by/4.0/

(c) (i) Open Access 